УДК 821.163.41-3.09

821.163.2-3.09

https://doi.org/10.18485/msc50.2019.1.ch64

Бојан Ничев

\title{
МЕСТО И ФУНКЦИЈА ПРИПОВЕТКЕ У НАРАТИВНОЈ КУЛТУРИ НОВЕ СРПСКЕ И БУГАРСКЕ КЬИЖЕВНОСТИ
}

Приповетка је одавно заузела своје одређено место у систему европских наративних књижевних врста. Ова чињеница, међутим, никако не олакшава питање о судбини овог жанра у једној регионалној групи као што су јужнословенске књижевности. Проблем није само у томе што се садржај ове наративне форме мењао у току деценија и столећа. Ствари су се компликовале још више тиме што је овај садржај добијао националну обојеност, одражавајући специфични развој једне националне књижевности као уметности речи. Оно што Бугари данас називају расказ, Руси - рассказ, Срби и Хрвати - приповетка, Енглези и Американци short story, Немци - Erzählung ... обележава у ствари кратку, на одређени начин организовану наративну форму. Али ови одређени принципи жанрове организације обично имају специфичне и временске и националне модификације. Па ипак, приповетка је приповетка. Приповетке су писане и даље се пишу. Она има своју историју и своју историјску поетику.

Дакле, ако бисмо хтели да посматрамо ову књижевну врсту у њеном реалном развитку, мислим да је најбоље да уместо да јој прилазимо нормативним дефиницијама, да потражимо њен развитак у оквиру читаве наративне културе једног народа или једног културног региона. Тим пре што је наративно искуство последњих столећа створило у Европи неке чврсте и одређене парадигме жанра које имају свој значај, али ипак не могу објаснити развој наше прозе према савременим облицима ове књижевне врсте.

Па ипак мислим да не бисмо могли проћи без било каквог начелног и наравно условног одређења теоретског карактера које би нам послужило као својеврстан кључ за тумачење жанра онако како се он схвата у класичном развитку европског реализма нашег века. Мислим да је најприхватљивија формула (уколико се ту може говорити о формулама) за јединицу наративности, за најмањи приповедачки модел, дао руски писац Алексеј Толстој када је рекао да је приповетка, односно сиже 
приповетке - „зарез плус али” (Запятая плюс но). „Сожет как всякий анегдот (опять подчеркиваю анегдот не как игра слов, а как предельный по лаконизму рассказ о столкновений фактов) не может мыслаться как причина и следствие, действие и результат, сила приложенная к данной среде и вытекающие отсюда последствия и т.д. В сюжете всегда должна быть запятая и „но”. К данной среде прикладывается сила, но возникает противсила и получается неожиданный (или заранее обреченный роковой) результат. Элемент неожиданности или - в другом случае - обреченности и состовляет столь анегдота".

Све се то наравно односи на кратке наративне форме. Али оно што је за нас најбитније у овом случају јесте да се овај контрапунктални склоп може пронаћи и код других наративних формација и врста. Навешћу само неколико обичних примера. Ево, рецимо познате Нушићеве приповетке Тринаести. Главни јунак приповетке, нижи чиновник, „вечити практикант”, читав живот машта о унапређењу. На крају га начелник позива на вечеру, и он намерава да га том приликом замоли за своје унапређење. Међутим, сад долази до изражаја поетички захтев „зарез плус али". За столом буде тринаест људи, па управо њега лепо замоле да изађе. Маштање ситног чиновника се не остварује, а цела приповетка се обликује од сличних ситуација везаних на тај начин - преко „зарез и али". Или узмимо, на пример, приповетку другачије стилизације, рецимо Матавуљеву приповетку Покајан гријех. Уочи Видовдана и почетка рата 1876. године у братству Перовића у Црној гори десило се нешто страшно и необично: млада удовица је добила дете „ван закона”. Село хоће да је каменује. Тада се кривац сам појављује и себе кажњава јуначком смрћу, онако како доликује једном Црногорцу. Радња добија неочекивани обрт. Створена је приповетка.

Примера може да буде више. Али се и из горенаведених, може запазити да ова формула нуди нешто попут језгра пре свега кратке прозе са сижеом. Наравно да то још није приповетка, да је то само увод у њену поетику. Да би се од овог модела стигло до приповетке потребно је још много ствари. Приповетка се остварује удаљавањем и враћањем овом моделу и свака посебна приповетка се односи према њему као варијанта према инваријанти. Али овај минимум наративности је основа на којој се приповетка повезује са митом, анегдотом, причом и другим специфичним наративним формама као што су нпр. фаблио, новела, и уопште облицима насталим у току европског књижевног развитка. Што се тиче

${ }^{1}$ Ал. Толстой, Что такое маленький рассказ. - Собрание сочинений 10 т. стр. 415-417. 
мита, приповетка је повезана са њим не само типолошки него и генетички. Зато је у наше доба и постало могуће да се у књижевној приповеци искористе неки архаични фолклорно-митолошки модели.

Настојећи да се ослоне на своје домаће традиције, на достигнућа своје наративне поетике, јужнословенске књижевности су се у формирању своје приповетке окренуле фолклорним наративним моделима, који носе у себи богате приповедачке могућности. Карактеристични примери у том погледу су Левстиков Мартин Крпан и Љубишин Катош Мацедоновић. Југословенска наука о књижевности већ је скренула пажњу на могућност упоређивања ових дела двојице јужнословенских писаца. Сасвим недавно је о томе писао Петар Џаџић, а нешто раније Јоже Погачник. ${ }^{2}$ И Мартин Крпан и Каночи Мацедоновић изграђени су према једном истом мотиву. Овај је мотив врло популаран, има много фолклорних и књижевних варијанти што значи да није једнозначан. Забележен је и у каталогу Арне-Томсона (Arne-Thompson). Састоји у томе што обичан и скроман младић спасава младу девојку, обично царску ћерку, и на крају се њоме жени. У овом мотиву садржане су бар две значајне интерпретационе варијанте. Прва од њих је везана за већ цитирани сиже: незнани јунак убија неку неман, неку напаст, неко чудовиште, неког негативног јунака. У таквом облику овај мотив ближе је миту о борби културног хероја и немани и повезан је са ранијом етапом развитка приповетке код Јужних Словена кад је она сасвим једноставно и природно настајала из фолклорне наративне културе.

У књижевности се овај мотив користи на својеврстан начин и даје своје специфичне модификације. У фолклорној варијанти главна наративна опозиција је у томе што веома познати јунаци не могу победити негативног хероја. Међутим, захваљујући негативном контрапункту (зарез плус али) побеђује га скромни непознати младић који пореклом, популарношћу, чак и својим спољашњим изгледом излази ван оквира рицарске норме. У књижевној модификацији наративни контрапункт је сасвим другачији. Мартин Крпан и Кањош Мацедоновић убијају Брадавса односно Фурлана, али одбијају да приме награду за своју победу. Нити се жене царским ћеркама, нити примају друге дарове. Ја се међутим нећу бавити тумачењем ових чињеница. Оне имају свој идејни значај о којем је доста писано. За нас је ту битно да овај значај ствара нове наративне структуре. Још битније је да ове структуре потичу из недара народне

${ }^{2}$ Ј. Погачник, Мартин Крпан и Катош Мацедоновић, у Норме и форме. Београд, 1981; П. Џаџић, Hото heroicus homo balcanicus, „Књижевност”, књ. 5, 8-9, 1984, c. 1331-1363. 
наративне културе, да се рађају на тлу старих фолклорно-митских наративних модела путем њихове трансформације. Улога ових трансформационих процеса очигледно је значајна и до сада није оцењена у науци о књижевности, јер у бугарској књижевности налазимо као врло функционалну за послератни бугарски роман једну другу трансформацију овог мотива. Ова трансформација је повезана са успехом неепског јунака (у другим верзијама најмлађи преварени брат, у руској верзији Иван-дурак) који се жени царском ћерком. На својеврсној дискретној трансформацији тог мотива изграђен је романескни склоп познатих бугарских романа „Дуван” Димитра Димова, готово сва четири романа тетралогије Димитра Талева ${ }^{3}$ и др. Мислим да није никако случајно и то што је позната совјетска књижевница Лидија Гинзбург пронашла трагове овог фолклорног мотива чак у романима Текерија. „В глубине самых сложных динамических систем - пише она - продолжают существовать традиционные роли, типологические модели. Но существование их коренным образом трансформировано, функции коренным образом нарушены... Структура романа нового времени основанная на переменных, непредрешенных отношениях не укладывается в схему. Но от схемы она что-то сохраняет. Не случайно в образе Добина, неуклюжего, всеми осмеянного, отвергнутого в самом деле проступает фольклорная роль гонимого „младшего брата”, который и оказывается самым умным, мушественным и благородныи".

За нас је ту најбитније да нагласимо да у овом развитку према модерним облицима приповедања јужнословенска приповетка је пронашла своје домаће традиције, својеврсне наративне форме које је изнела из своје многогодишње приповедачке културе и на које се могла ослонити у свом модерном развитку. Ту морам рећи да у појам „наративне културе” не спадају само митско-фолклорне традиције, да је овај појам врло широк али је ипак конкретно историјски одређен. Ту улази и приповедачко ускуство старих јужнословенских књижевности које још није постало уметност речи у модерном смислу. Патеричке приповетке, ${ }^{5}$ хагиографска проза књижевноисторијски и генетички јесу пут ових књижевности према модерној приповеци. Овај пут је у многоме заједнички за средњовековну српску и за стару бугарску књижевност. На жалост

${ }^{3}$ Б. Ничев, Съвременият български роман. Към историята и теорията на епичното в съвременната българска латература.

4 Л. Гинзбург, О структуре титературного персонажа. - „Искуство слова”, M. 1973 , с. 378 .

5 С. Николова, Патеричните разкази о българската средновековна литераmypa. C, 1980. 
ово књижевно подручје није довољно проучено у овом смислу и ја бих овом приликом само поменуо ово питање.

Савремена приповетка у модерном смислу се код Бугара и Срба јавља релативно касно, у доба реализма. Али ту не можемо мимоићи развитак приповедачке уметности пре тога. Ту треба имати у виду таква достигнућа српске прозе као што су Вукова проза, мемоаристика проте Матије Ненадовића код Срба, а код Бугара - етнографска документаристика и публицистика Љубена Каравелова, мемоарна проза Захарија Стојанова, хумористичка портретистика Ивана Вазова (мислим на његову галерију портрета паланачких типова „Чичовци”). Ту се наравно не разрађује читав модел приповетке, већ само неки њени елементи. Наилазимо на достигнућа која су од великог значаја за будући развој мањих и већих наративних књижевних врста. Ова проза је у ствари својеврстан лабораторијум у коме се разрађује техника модерног уметничког приповедања, уметничког креирања људског лика, различите форме приповедачке присутности односно приповедачке одсутности у нарацији. Или још тачније речено: у овој прози (која се у извесном смислу може назвати наивном) постављају се основи модерне наративне фикције.

Велику улогу у овом процесу, у стварању модерне наративне фикције одиграла је књижевна трансформација фолклорног сказа. Сказ је специфична особина словенске наративне културе. Толико специфична да је тешко чак и сам термин „сказ” превести на стране, несловенске језике. Руски формалисти су први озбиљно покренули ово питање. Већ сам имао могућност да скренем пажњу на велику разлику између фолклорног сказа и његове трансформације ${ }^{6}$ на значај прелаза од њега према њој у естетичком развитку Јужних Словена. Ова трансформација дала је и приповеци велике могућности у области наративне технике. Што се тиче диспозиције конфликта, увођења јунака у радњу, стварања од усменог приповедача уметничке функције наратора итд., трансформација сказа је понудила јужнословенској приповеци велике могућности. И она их је искористила.

У чему је ствар. Давно је већ речено да балкански човек не „даје информацију", не обавештава. Он прича, чак и када треба нешто да саопшти. Ако, рецимо, хоће да каже, да је јуче био на пијаци, он ће још издалека почети, испричаће разне детаље који нису у вези са основном информацијом. И тако се губи информација као циљ комуникације и причање постаје само себи циљ. Исто као у Хиљаду и једној ноћи. Очигледно ово није особина само балканског мишљења. Оно се може про-

${ }^{6}$ Б. Ничев, Увод в јужнославянския реализъм. С. 1971, с. 187-207. 
наћи још у антици. Познати истраживач античког мишљења Франкел каже да код Омира радња иде са свим детаљима који је прате. Кад Омир хоће да наслика ручак он ће почети још од тога како убијају овна за овај ручак. Дакле ова особина античког мишљења постала је у балканској нарацији својеврстан стил комуникације. И одатле је прешла у фолклор и у литературу. Јер у овом причању, у овој нарацији, ствара се једна друга слика живота, појављују се неочекиване асоцијације и унутрашње везе, раскрива се лик приповедача. Као што је тачно приметио Д. Вученов, наратор у Лазаревићевој приповеци постаје наследник усменог приповедача. ${ }^{7}$ Код великог броја српских и бугарских писаца из последње трећине прошлог века па све до почетка овог, то је још уочљивије. Исто се може приметити и код Глишића, Веселиновића, Сремца, Кочића у српској и код Каравелова, Михалаки Георгијева и др. у бугарској књижевности. Ови писци обележавају прву фазу присутности сказа у поетици српске и бугарске приповетке. То је фаза књижевне транформације $\phi$ о л к л орн ог сказа а. Касније, већ у нашем времену сказ ће се поново јавити у бугарској и српској књижевности али већ са другим функцијама, функцијама асоцијативне прозе. Довољно је само да нагласимо значај овог наративног поступка код савремених аутора као што су Јордан Радичков код Бугара или Драгослав Михајловић код Срба. Ово је друга фаза присутности сказа у поетици бугарске и српске приповетке - ф а з а књи жевн е стилизаци ј е сказа. Ове две фазе треба разликовати. Разлика међу њима је битна. Али мислим да је у овом случају најбитније оно што бих и хтео да подвучем: да је у заокретним фазама свог развитка и стварања као европска књижевна врста приповетка код Јужних Словена нашла своје својеврсне традиције на оном тлу на коме се и развијала.

Постоји још једно интересантно питање које је везано за однос приповетке према роману у бугарској и српској књижевности. До сада смо говорили само о формирању приповетке, о томе како наративна уметност Јужних Словена долази до савремених облика ове древне књижевне врсте, о путу нарације ка приповеци. Сада бих хтео само да се дотакнем супротног питања: то јест пута од приповетке према већим облицима књижевне нарације, односно према роману у бугарској и српској књижевности. Ту се може приметити извесна функционална активизација збирки приповедака, приповедачких циклуса, који ту добијају извесну специфичну улогу, улогу извесне специфичне жанровске формације.

7 Д. Вученов, Понешто о структури Лазаревићеве приповетке „Први пут с оцем на јутрене", у О српским реалистима и юиховим претходницима, Београд, 1970, c. 91-106. 
Бугарски књижевни историчари су већ одавно запазили да неке збирке приповедака утичу као целина, да оне нису просто збир тематски везаних или невезаних приповедака каква је свака обична збирка, већ да имају своју унутрашњу структуру; јединство места и неке заједничке јунаке. Књиге ове врсте појављују се у бугарској књижевности још од краја прошлог века и што је најбитније - то су обично књиге трајне уметничке вредности, у којима њихови аутори покушавају да постигну социјалну или народнопсихолошку синтезу. Пре свега ту треба споменути познату књигу Алека Константинова Бай Ганьо (1895) која у ствари представља циклус приповедака и фељтона са одређеним центром - ликом главног јунака. Ту треба још споменути познате књиге класичне за бугарску књижевност као што су Драски и шарки Ивана Вазова (1895), Вечери с Антимовския хан (1928) и Ако можеха да говорят (1938) Јордана Јовкова. На крају ту се може споменути и познати роман Г. Караславова Танго који је у ствари новелистички триптих. Очигледно је да ове форме на свој начин одговарају друштвеним приликама овог доба на словенском југу. Роман (мислим на социјални реалистички роман) захтева друштвену целину. А социјални услови за изграђивање поетике већих романескних структура, вишеслојних наративних композиција и сложених сижејних целина, сазревали су ту споро. И формације циклизираних приповедака надокнађивале су помањкање романескне епичности. Оне су стварале једну својеврсну романескну поетику адекватну неразвијеној епичности буржоаског друштва. Јер ако је роман у то доба био као што је Хегел рекао, буржоаска епопеја, у неразвијеном буржоаском друштву морају постојати адекватне структуре и поетика за ове неразвијености. Али то што бих хтео овде да нагласим јесте да ова „предроманескна” поетика циклизације приповедака није прилагођавање туђим, страним облицима него самостално откриће у феноменологији епичности, откриће које познаје своја висока достигнућа. Једно од њих је стваралаштво Иве Андрића. Андрић је у ствари велики мајстор циклизираних наративних структура. Управо код њега историјска неопходност и естетска самосталност овог феномена долазе до најснажнијег израза. Андрићев најбољи роман На Дрини ћуприја је „федерација” новела које су спољашње повезане јединством места радње и ликом приповедача. Али и пре тога у својој новелистици, која је својеврсни лабораторијум за његов романескни рад, Иво Андрић је разрађивао форму новелистичког циклуса - у Алији Ђерђелезу, у циклусу о фратрима.

Знатно касније у послератној бугарској и српској књижевности циклизација приповедака се поново јавља, али са супротном функцијом. То је функција активне деепизације, то је потреба за удаљавањем од епске 
поетике у годинама после великог „доба романа”. У ово време књижевност поново тражи форму новелистичког циклуса који је у њој имао велику традицију. Он је пре више деценија створио ту своју каријеру и она га поново искоришћава мењајући његову функцију. Ова форма се јавља као поступак за редукцију обичне романескне фабуларности и епске дескрипције, као корак према новом савременом изразу.

Дакле, код циклизације приповедака, као и код сказа можемо запазити два супротна периода функционисања: први је епски цент рипетална циклизација (ако могу да употребим једну метафору) други се може назвати е п ски це н т р и фуга л ном.

Све ово говори о флексибилности и специфичности књижевних форми у јужнословенским књижевностима; о томе да оне на свој начин решавају битна питања наративне поетике, ослањајући се на своје традиције. У овом кратком упоредном прегледу хтео сам да подвучем нека питања историјске поетике бугарске и српске приповетке и њен значај у наративној култури Јужних Словена. 